\title{
Suppression Effect of Superoxide Dismutase (SOD)-Like Activity Protein Partially Purified from Raphnus sativus Leaves against Liver Metastasis in Mice Intraperitoneally Infected with Ehrlich Ascites Carcinoma Cell
}

\author{
El-Shahat A. Toson', Fahed M. Almutairi'2, Amira Ali Elfalal ${ }^{3}$, Salem A. Habib ${ }^{1,2}$, \\ Rasha F. Zahran', Mohamed Elbakry ${ }^{2,4}$ \\ ${ }^{1}$ Division of Biochemistry, Department of Chemistry, Faculty of Science, Damietta University, Damietta, Egypt \\ ${ }^{2}$ Department of Biochemistry, Faculty of Science, University of Tabuk, Tabuk, Kingdom of Saudi Arabia \\ ${ }^{3}$ Department of Botany, Faculty of Science, Damietta University, Damietta, Egypt \\ ${ }^{4}$ Division of Biochemistry, Department of Chemistry, Faculty of Science, Tanta University, Tanta, Egypt \\ Email: dr_salem_habib@yahoo.com
}

Received 25 April 2016; accepted 9 July 2016; published 12 July 2016

Copyright (C) 2016 by authors and Scientific Research Publishing Inc.

This work is licensed under the Creative Commons Attribution International License (CC BY).

http://creativecommons.org/licenses/by/4.0/

c) (i) Open Access

\section{Abstract}

Liver metastasis is a normal result in Ehrlich Ascites Carcinoma Cell (EAC) infected mice. A partially purified protein with Superoxide Dismutase (SOD)-like activity extracted from leaves of Raphnus sativus was tested for its ability to down regulate liver metastasis of Ehrlich Ascites Carcinoma Cell (EAC) intraperitoneally implanted in albino mice. Sixty albino mice were divided equally into 4 groups. Group I mice (G1 control) were treated with physiologic saline solution for 7 days. Group 2 mice (G2) were injected with the partially purified protein. Group 3 mice (G3) were intraperitoneally inoculated with EAC cells and treated with the partially purified protein. Group 4 mice (G4) were inoculated EAC cells and treated with physiologic saline solution. The results showed a disturbance in liver functions. This disturbance was observed as a reduction in the values of serum albumin, hemoglobin, total counts of erythrocytes and platelets, total lipids in liver tissues, erythrocytes SOD activity, serum glucose, reduced glutathione (GSH) and the trace elements (Fe, $\mathrm{Mn}, \mathrm{Zn}$, and $\mathrm{Cu}$ ) contents in liver and spleen tissues as well as the elevation of serum transaminases activities, the levels of malondialdehyde in blood, DNA and RNA of liver tissues in the infected mice (G4). On the other hand, in G3, after treatment with the partial purified protein all these parameters restored their normal values and became near from the normal group (GI). Moreover, the protein showed no toxicity towards the mice as shown in G2. It could be concluded 
that a partially purified protein with Superoxide Dismutase (SOD)-like activity extracted from leaves of Raphnus sativus as a nature source has a promised future in controlling liver metastasis.

\title{
Keywords
}

\author{
Apoptosis, Transformed Cells, Raphnus sativus, SOD-Like Activity, EAC Cells, Liver Metastasis
}

\section{Introduction}

Oxygen free radicals or, more generally, Reactive Oxygen Species (ROS), as well as reactive nitrogen species (RNS), are products of normal cellular metabolism. ROS and RNS are well recognized for playing a dual role; they can be either harmful or beneficial to living systems [1] [2]. Beneficial effects of ROS occur at low/ moderate concentrations in defense against infectious agents, in the function of a number of cellular signaling systems, and in the induction of a mutagenic response.

The potential biological damage is the harmful effect caused by the oxidative and nitrosative stress [3]. This occurs in the biological systems when the overproduction of ROS/RNS leads to a disturbance in the oxidants/ anti-oxidant balance in the biological cell. In other words, oxidative stress results from the metabolic reactions that use oxygen and can damage cellular lipids, proteins, or DNA inhibiting their normal function. Consequently, oxidative stress has been implicated in a number of human diseases as well as in the ageing process. The delicate balance between beneficial and harmful effects of free radicals is a very important aspect of living organisms and is achieved by mechanisms called "redox regulation". The process of "redox regulation" protects living organisms from various oxidative stresses and maintains "redox homeostasis" by controlling the redox status in vivo [4] [5]. Many physiological functions depend on a balance between reactive species (e.g. reactive oxygen and nitrogen compounds) and antioxidant defenses [5] [6].

There are numerous mechanisms by which cells protect themselves against oxidants. The most important $\mathrm{H}_{2} \mathrm{O}_{2}$-scavenging enzymes and related proteins with antioxidant capability include catalase, glutathione peroxidases, glutathione reductases and enzymes associated with the synthesis of reduced glutathione (GSH) (such as $\gamma$-glutamyl cysteine synthase) [7].

Superoxide Dismutases (SODs) are metalloenzymes that also catalyze thedismutation of superoxide anions into molecular oxygen and hydrogenperoxide; they represent a major cellular defense mechanism involved in the neutralization of ROS in both prokaryotic and eukaryoticorganisms. They have been found in nearly all organisms and play a major role in the defense against oxidative stress [8]. At high concentrations, ROS can be important mediators of damage to cell structures, nucleic acids, lipids and proteins [1]. The hydroxyl radical is known to react with all components of the DNA molecule, damaging both the purine and pyrimidine bases and also the deoxyribose backbone. The most extensively studied DNA lesion is the formation of 8-hydroxyguanosine. Permanent modification of genetic material resulting from these "oxidative damage" incidents represents the first step involved in mutagenesis, carcinogenesis and ageing [5]. In addition, a redox imbalance subsequently induces liver tumor-promoting effects by enhancing cellular proliferation in rats [9].

The increased SOD activity decreases superoxide content in the cells and thus reduces the ROS-mediated stimulation of cell growth. It may be hypothesized that Manganese Superoxide Dismutase (MnSOD) would decrease cancer cell proliferation indirectly through reduction of ROS, unlike conventional tumor suppressors, which regulate cell growth and decrease expression of cancer cells [10]. Consequently suppression of liver metastasis may be expected.

Liver metastasis is a cancerous tumor that started in neighboring organs such as breast, colon rectum and kidney. It is also called secondary liver cancer or metastatic liver disease. Liver metastasis is not the same as cancer that originates in the liver, called primary liver cancer. The risk of liver metastasis depends on the location of the original cancer. Unfortunately there may be no symptoms in the early stages of liver metastasis. In later stages, cancer can cause the liver to swell including loss of appetite weight loss dark colored urine [11]-[13].

Raphnus sativus (Radish) is an annual herb, consumed as vegetable. It belongs to the family Brassicaceae. It has been used in folk medicine as a natural drug against many toxicants. It decreases blood glucose levels in diabetic rats [14] and improves the histopathology of colon mucosa in the rats fed high fat diet [15] [16]. Its anti- 
oxidant effects are reported in alimentary hyperlipidemic rats [17]. Radish extract improves the antioxidant status of male mice and can overcome or, at least, significantly diminish mycotoxin (Zearalenone) effects [18]. Therefore, a partially purified extract from the leaves of Raphnus sativus was examined for its anti-tumor effect and suppression of liver metastasis in Ehrlich Ascites Carcinoma (EAC) bearing mice.

\section{Materials and Methods}

\subsection{Materials}

\subsubsection{Animals and Tumor Cell Line}

Adult female Swiss common-bred albino mice were purchased from Theodore BilharzInistitute, Giza, Egypt, with an average body weight of 25 to 30 g. EACcells kindly supplied by the National Cancer Institute, Cairo University, Egypt, were injected intraperitoneally in the mice. The parent cell line was the tumor cell line maintained in mice through serial intraperitoneal transplantations of $1 \times 10^{6}$ EAC cells in $0.2 \mathrm{ml}$ of saline [19]. The mice were randomly divided into 4 groups of 15 animals each as follows:

1) Group 1: Normal mice-saline treated (control) (G1)

Each mouse of this group was intraperitoneally injected with $200 \mu \mathrm{l}$ of the physiological saline solution for 7 days.

2) Group 2: Normal mice-Raphnus sativus extract treated (G2)

Each mouse was intraperitoneallyinjected with $4.0 \mathrm{mg}$ protein/kg/day (200 $\mu \mathrm{l})$ Raphnus sativus extract for 7 days.

3) Group 3: EAC-bearing mice-Raphnus sativus extract treated (G3)

Each mouse was intraperitoneallyinoculated with $1 \times 10^{6}$ tumor cells. After 24 hours of tumor inoculation, the mice were intraperitoneallyinjected with (200 $\mu \mathrm{l}) 4.0 \mathrm{mg}$ protein/kg/day Raphnus sativus extract for 7 days.

4) Group 4: EAC-bearing mice-saline treated (G4)

Each mouse was intraperitoneally inoculated with $1 \times 10^{6}$ tumor cells. After 24 hours of tumor inoculation, the mice were intraperitoneallyinjected with $200 \mu \mathrm{l}$ of the physiological saline solution for 7 days.

\subsubsection{Samples}

Three weeks after the last treatment, ascetic fluid was individually withdrawn from each mouse of G4 and measured. Liver and spleen samples were quickly dissected, rinsed with isotonic saline and dried. $0.25 \mathrm{~g}$ of these tissues was homogenized in ice cooled saline and diluted to yield a $5 \%(w / v)$. The supernatant was used for biochemical analysis. Blood samples were collected by tail vein cutting and their sera were used.

\subsection{Methods}

\subsubsection{Preparation of Raphnus sativus Extract}

$150 \mathrm{~g}$ of leaves tissues of Raphnus sativus were homogenized with $500 \mathrm{ml}$ ice cooled Tris buffer $(0.10 \mathrm{M}, \mathrm{pH}$ 8.3). The homogenate was precipitated with $70 \%\left(\mathrm{NH}_{4}\right)_{2} \mathrm{SO}_{4}$. The precipitate was chromatographed on calcium phosphate gel ( $\mathrm{pH}$ 7.0). The enzyme was then eluted with serial concentrations of $\mathrm{NaCl}$. The purified enzyme was dialyzed against bidistilled water and then concentrated using polyethyleneglycol. The concentrated purified enzyme was reconstituted with Tris buffer (0.10 M, pH 8.3).

\subsubsection{Biochemical Tests}

Total proteins were determined in the extract by the modified method of Folin Lowry [20]. Iron (Fe), Manganese (Mn), Zinc (Zn) and Copper (Cu) were estimated in Raphnus sativus extract, liver tissues and spleen tissues by Atomic AbsorptionSpectrophotometery according to the method of [21]. According to the method of [22], nucleic acids were extracted from liver homogenate. DNA content was determined colorimetrically in the extract using diphenylamine procedure described by [23], and RNA content was measured by the orcinol procedure described by [24] [25]. The method of [26] was usedfor the extraction of lipids. Total lipids in liver tissues were determined by the method of [26]. Lipids profile which include triglyceride, total cholesterol, high density lipoprotein-cholesterol (HDL-C) andlow density lipoproteins (LDL) were done in serum using commercial kit (Biocon's India) according to the instruction of the manufacturer. Glucose in serum was determined enzymatically according to the method of [22]. Alanine transaminase (ALT) and aspartate transaminase (AST) activities 
in serum were determined by the method of [27]. Serum albumin concentration was determined by the method of [28] [29]. Erythrocyte reduced glutathione (GSH) was determined by the method of [30]. Malondialdehyde (MDA) was determined in the blood by the method of [31]. Superoxide dismutase (SOD) activity in serum was assayed by the method of [32]. Blood hemoglobin $(\mathrm{Hb})$ concentration was colourimetrically determined according to the method of [33]. Total count of $\mathrm{WBC}_{\mathrm{s}}$ and Platelets were determined according to the technique described by [34]. For this assay an advanced Bright-LineHaemocytometer was used (Bosch and Lomb USA).

\subsection{Statistical Analysis}

The statistical analyses of the results were carried out using Instate software computer program, version 2.03 (Graph pad, USA) and IBM PC compatible computer. The one tailed P-values tables were used for statistical analysis. A difference was said to be significant, and highly significant, when the corresponding level of probability (P) was $\leq 0.05$ and $\leq 0.001$, respectively. Correlation coefficient ( $\mathrm{r}$ ) was used for measuring the relationship between two variables. The correlation is weak at $r=0.50$, moderate at $r=0.50-0.75$ and strong at $r=0.80$ 1.00 .

\section{Results}

The concentration of metal ions in the partially purified SOD-like activity from Raphnus sativus leave's extract showed that, the extract contains $\mathrm{Cu}, \mathrm{Mn}, \mathrm{Fe}$ and $\mathrm{Zn}$ in concentration 0.002, 0.0065, 0.080 and $0.076 \mu \mathrm{g} / \mathrm{mg}$ protein respectively, with total protein $60.5 \mathrm{mg} \%$ and SOD activity $86 \%$ (\% of inhibition).

The obtained results of different mice groups are summarized in Tables 1-8.

Table 1. Total count of white blood cells and platelets, Hb concentration and tumor volume in mice of groups I, II, III and IV.

\begin{tabular}{|c|c|c|c|c|c|}
\hline \multicolumn{2}{|c|}{ Parameter group } & White blood cells count $\times 10^{3} / \mu \mathrm{l}$ & Platelets count $\times 10^{3} / \mu \mathrm{l}$ & $\mathrm{Hb}(\mathrm{gm} \%)$ & Tumor volumes (ml) \\
\hline \multirow{2}{*}{ Group I } & Mean \pm SD & $6.0 \pm 1.3$ & $342.0 \pm 28.0$ & $13.55 \pm 0.3$ & 0 \\
\hline & $\mathrm{n}$ & 15 & 15 & 15 & 15 \\
\hline \multirow{2}{*}{ Group II } & Mean \pm SD & $5.3 \pm 1.7$ & $250.0 \pm 18.0^{* *}$ & $13.6 \pm 0.4$ & 0 \\
\hline & $\mathrm{n}$ & 15 & 15 & 15 & 15 \\
\hline \multirow{2}{*}{ Group III } & Mean \pm SD & $10.5 \pm 1.58^{* * b}$ & $248.0 \pm 20.0^{* * a}$ & $14.2 \pm 0.7^{\mathrm{a}}$ & 0 \\
\hline & $\mathrm{n}$ & 15 & 15 & 15 & 15 \\
\hline \multirow{2}{*}{ Group IV } & Mean \pm SD & $7.9 \pm 1.58$ & $142.0 \pm 17.0^{* *}$ & $9.4 \pm 1.2^{* *}$ & $16.0 \pm 4.0$ \\
\hline & $\mathrm{n}$ & 10 & 13 & 15 & 15 \\
\hline
\end{tabular}

$\mathrm{N}$ : number of cases. ${ }^{*}$ Significant $(\mathrm{P}<0.05)$ and ${ }^{* *}$ Highly significant $(\mathrm{P}<0.001)$ when groups II, III and IV compared to the values of group I. a $=$ highly significant $(\mathrm{P}<0.001)$ and $\mathrm{b}=$ significant $(\mathrm{P}<0.05)$ when group III compared to group IV. Group I (saline treated-normal mice), group II (Raphanus sativus extract treated-normal mice), group III (tumor bearing-Raphanus sativus extract treated mice) and group IV (tumor bearing-saline treated mice).

Table 2. Serum activities of sGOT and sGPT and serum albumin level in mice of groups I, II, III and IV.

\begin{tabular}{|c|c|c|c|c|}
\hline \multicolumn{2}{|c|}{ Parameter group } & sGPT (units/ml) & sGOT (units/ml) & Albumin (gm \%) \\
\hline \multirow{2}{*}{ Group I } & Mean \pm SD & $12.0 \pm 10.0$ & $16.0 \pm 6.0$ & $3.5 \pm 0.2$ \\
\hline & $\mathrm{n}$ & 15 & 12 & 12 \\
\hline \multirow{2}{*}{ Group II } & Mean \pm SD & $13.5 \pm 5.0$ & $17.0 \pm 5.0$ & $4.5 \pm 0.5$ \\
\hline & $\mathrm{n}$ & 12 & 15 & 12 \\
\hline \multirow{2}{*}{ Group III } & Mean \pm SD & $14.8 \pm 5.0^{\mathrm{a}}$ & $10.6 \pm 6.0^{\mathrm{a}}$ & $4.0 \pm 0.6^{\mathrm{a}}$ \\
\hline & $\mathrm{n}$ & 15 & 15 & 15 \\
\hline \multirow{2}{*}{ Group IV } & Mean \pm SD & $36.0 \pm 1.0^{* *}$ & $25.0 \pm 10.0^{*}$ & $2.0 \pm 0.4^{* *}$ \\
\hline & $\mathrm{n}$ & 15 & 12 & 12 \\
\hline
\end{tabular}


Table 3. Blood levels of glucose, GSH, MDA and SOD activity in mice of groups I, II, III and IV.

\begin{tabular}{|c|c|c|c|c|c|}
\hline \multicolumn{2}{|c|}{ Parameter group } & Glucose (mg \%) & SOD (\% of inhibition) & MDA $\times 10^{-7}$ (moles $/ 1 \mathrm{ml}$ packed cells) & GSH (m moles per ml cells) \\
\hline \multirow{2}{*}{ Group I } & Mean \pm SD & $92.0 \pm 19.0$ & $49.0 \pm 2.0$ & $66.0 \pm 10.0$ & $1.7 \pm 0.2$ \\
\hline & $\mathrm{n}$ & 15 & 15 & 12 & 10 \\
\hline \multirow{2}{*}{ Group II } & Mean \pm SD & $88.0 \pm 12.0$ & $46.0 \pm 1.0$ & $71.0 \pm 15.0$ & $1.5 \pm 0.01$ \\
\hline & $\mathrm{n}$ & 15 & 12 & 12 & 15 \\
\hline \multirow{2}{*}{ Group III } & Mean \pm SD & $69.0 \pm 21.0^{\mathrm{b}}$ & $57.0 \pm 9.0^{* a}$ & $65.5 \pm 12.0^{\mathrm{a}}$ & $1.9 \pm 0.09^{\mathrm{a}}$ \\
\hline & $\mathrm{n}$ & 15 & 15 & 12 & 12 \\
\hline \multirow{2}{*}{ Group IV } & Mean \pm SD & $39.0 \pm 20.0^{* *}$ & $32.0 \pm 3.0^{* *}$ & $129.0 \pm 30.0^{* *}$ & $1.2 \pm 0.07^{*}$ \\
\hline & $\mathrm{n}$ & 15 & 12 & 12 & 12 \\
\hline
\end{tabular}

Table 4. Serum levels of cholesterol, triglycerides, HDL-C and LDL and liver tissues total lipids in mice of groups I, II, III and IV.

\begin{tabular}{ccccccc}
\hline \multicolumn{2}{r}{ Parameter group } & Cholesterol (mg \%) & Triglycerides (mg \%) & HDL (mg \%) & LDL (mg \%) & Total lipids in liver tissues (mg \%) \\
\hline \multirow{2}{*}{ Group I } & Mean \pm S.D & $98.0 \pm 7.0$ & $87.0 \pm 23.0$ & $48.0 \pm 4.0$ & $47.0 \pm 6.0$ & $83.0 \pm 18.0$ \\
& $\mathrm{n}$ & 15 & 15 & 15 & 15 & 15 \\
Group II & Mean \pm S.D & $97.0 \pm 12.0$ & $90.0 \pm 16.0$ & $52.0 \pm 3.0$ & $31.0 \pm 7.0^{*}$ & $78.0 \pm 22.0$ \\
& $\mathrm{n}$ & 15 & 15 & 15 & 15 & 15 \\
Group III & Mean \pm S.D & $91.0 \pm 10.0^{\mathrm{a}}$ & $92.0 \pm 9.0^{\mathrm{a}}$ & $34.0 \pm 6.0^{* \mathrm{a}}$ & $45.0 \pm 9.0^{\mathrm{a}}$ & $78.0 \pm 26.0$ \\
& $\mathrm{n}$ & 15 & 15 & 15 & 15 & 15 \\
Group IV & Mean \pm S.D & $158.0 \pm 19.0^{* *}$ & $146.0 \pm 10.0^{* *}$ & $16.0 \pm 5.0^{* *}$ & $117.0 \pm 21.0^{* *}$ & $61.0 \pm 24.0^{*}$ \\
& $\mathrm{n}$ & 15 & 15 & 15 & 15 & 10 \\
\hline
\end{tabular}

Table 5. Weights of liver and spleen and levels of DNA and RNA in liver tissues of mice of groups I, II, III and IV.

\begin{tabular}{cccccc}
\hline \multicolumn{2}{c}{ Parameter group } & Liver weight $(\mathrm{gm})$ & Spleen weight $(\mathrm{gm})$ & DNA $(\mu \mathrm{g} / \mathrm{mg}$ tissue $)$ & RNA $(\mu \mathrm{g} / \mathrm{mg}$ tissue) \\
\hline \multirow{2}{*}{ Group I } & Mean \pm SD & $1.6 \pm 0.3$ & $0.182 \pm 0.07$ & $98.0 \pm 7.0$ & $123 \pm 6$ \\
& $\mathrm{n}$ & 13 & 12 & 12 & 12 \\
Group II & Mean \pm SD & $1.7 \pm 0.3$ & $0.21 \pm 0.05$ & $87.0 \pm 19.0$ & $126.0 \pm 9.0$ \\
& $\mathrm{n}$ & 9 & 6 & 12 & 12 \\
Group III & Mean \pm SD & $1.3 \pm 0.08^{\mathrm{b}}$ & $0.18 \pm 0.03^{\mathrm{a}}$ & $64.0 \pm 22.0^{* * a}$ & $98.0 \pm 14.0^{* * a}$ \\
& $\mathrm{n}$ & 12 & 13 & 12 & 15 \\
Group IV & Mean $\pm \mathrm{SD}$ & $0.95 \pm 0.09^{* *}$ & $0.06 \pm 0.02^{* *}$ & $199.5 \pm 27.0^{* *}$ & $196.0 \pm 16.0^{* *}$ \\
& $\mathrm{n}$ & 10 & 10 & 12 & 12 \\
\hline
\end{tabular}

Table 6. Some correlations in all groups, liver DNA, RNA and MDA with GSH, SOD, glucose, albumin, HDL, triglycerides, LDL and SGPT.

\begin{tabular}{|c|c|c|c|c|c|c|c|c|}
\hline Parameters & $\begin{array}{l}\text { GSH (m moles/ml } \\
\text { cells) }\end{array}$ & $\begin{array}{c}\text { SOD } \\
\text { (\% of inhibition) }\end{array}$ & $\begin{array}{l}\text { Glucose } \\
\text { (mg \%) }\end{array}$ & $\begin{array}{l}\text { Albumin } \\
\text { (gm \%) }\end{array}$ & $\begin{array}{c}\text { HDL } \\
(\mathrm{mg} \%)\end{array}$ & $\begin{array}{l}\text { Triglycerides } \\
\text { (mg \%) }\end{array}$ & $\begin{array}{c}\text { LDL } \\
(\mathrm{mg} \%)\end{array}$ & SGPT (units/ml) \\
\hline $\begin{array}{c}\text { DNA } \\
(\mu g / m g \\
\text { protein) }\end{array}$ & ns & $\begin{array}{l}r=-0.93 \\
P<0.001\end{array}$ & $\begin{array}{l}r=-0.59 \\
P=0.005\end{array}$ & ns & $\begin{array}{l}r=-0.5 \\
P=0.02\end{array}$ & ns & $\begin{array}{c}r=0.88 \\
P<0.0001\end{array}$ & $\begin{array}{l}R=0.79 \\
P<0.001\end{array}$ \\
\hline $\begin{array}{c}\text { RNA } \\
(\mu g / m g \\
\text { protein) }\end{array}$ & $\begin{array}{c}r=-0.76 \\
P<0.0001\end{array}$ & $\begin{array}{c}r=-0.87 \\
P<0.0001\end{array}$ & $\begin{array}{c}r=-0.5 \\
P=0.007\end{array}$ & $\begin{array}{l}r=-0.86 \\
P<0.0001\end{array}$ & ns & $\begin{array}{c}r=0.86 \\
P<0.0001\end{array}$ & $\begin{array}{c}r=0.88 \\
P<0.0001\end{array}$ & $\begin{array}{c}r=0.82 \\
P<0.0001\end{array}$ \\
\hline $\begin{array}{c}\text { MDA } \\
\text { (Moles/ml } \\
\text { packed cells) }\end{array}$ & $\begin{array}{l}r=-0.54 \\
P=0.013\end{array}$ & ns & ns & ns & $\begin{array}{c}r=-0.80 \\
P<0.0001\end{array}$ & $\begin{array}{c}r=0.85 \\
P<0.0001\end{array}$ & $\begin{array}{c}r=0.92 \\
P<0.0001\end{array}$ & $\begin{array}{c}r=0.81 \\
P<0.0001\end{array}$ \\
\hline
\end{tabular}


Table 7. Concentrations of iron, manganese, zinc and copper in spleen tissues of mice of groups I, II, III and IV.

\begin{tabular}{|c|c|c|c|c|c|}
\hline \multicolumn{2}{|c|}{ Parameter group } & $\begin{array}{c}\text { Fe } \\
\text { ( } \mu \mathrm{g} / \mathrm{gm} \text { tissue) }\end{array}$ & $\begin{array}{c}\text { Mn } \\
\text { ( } \mu \mathrm{g} / \mathrm{gm} \text { tissue) }\end{array}$ & $\begin{array}{c}\mathrm{Zn} \\
\text { ( } \mu \mathrm{g} / \mathrm{gm} \text { tissue) }\end{array}$ & $\begin{array}{c}\mathrm{Cu} \\
(\mu \mathrm{g} / \mathrm{gm} \text { tissue })\end{array}$ \\
\hline \multirow{2}{*}{ Group I } & Mean \pm SD & $20.5 \pm 3.0$ & $0.8 \pm 0.2$ & $62.6 \pm 24.0$ & $0.47 \pm 0.2$ \\
\hline & $\mathrm{n}$ & 6 & 6 & 6 & 6 \\
\hline \multirow{2}{*}{ Group II } & Mean \pm SD & $17.5 \pm 2.8$ & $0.6 \pm 0.05$ & $35.0 \pm 10.9^{*}$ & $0.28 \pm 0.05^{*}$ \\
\hline & $\mathrm{n}$ & 6 & 6 & 6 & 6 \\
\hline \multirow{2}{*}{ Group III } & Mean \pm SD & $21.0 \pm 4.5^{\mathrm{b}}$ & $1.4 \pm 0.28^{* *_{a}}$ & $53.6 \pm 14.7^{\mathrm{a}}$ & $0.43 \pm 0.07$ \\
\hline & $\mathrm{n}$ & 15 & 15 & 15 & 15 \\
\hline \multirow{2}{*}{ Group IV } & Mean \pm SD & $14.7 \pm 3.4^{*}$ & $0.5 \pm 0.39$ & $20.0 \pm 9.8^{* *}$ & $0.27 \pm 0.01^{*}$ \\
\hline & $\mathrm{n}$ & 10 & 10 & 10 & 10 \\
\hline
\end{tabular}

Table 8. Concentrations of iron, manganese, zinc and copper in liver tissue of mice of groups I, II, III and IV.

\begin{tabular}{|c|c|c|c|c|c|}
\hline \multicolumn{2}{|c|}{ Parameter group } & $\begin{array}{c}\text { Fe } \\
\text { ( } \mu \mathrm{g} / \mathrm{gm} \text { tissue) }\end{array}$ & $\begin{array}{c}\text { Mn } \\
\text { ( } \mu \mathrm{g} / \mathrm{gm} \text { tissue) }\end{array}$ & $\begin{array}{c}\mathrm{Zn} \\
\text { ( } \mu \mathrm{g} / \mathrm{gm} \text { tissue) }\end{array}$ & $\begin{array}{c}\mathrm{Cu} \\
(\mu \mathrm{g} / \mathrm{gm} \text { tissue })\end{array}$ \\
\hline \multirow{2}{*}{ Group I } & Mean \pm SD & $27.0 \pm 8.9$ & $0.71 \pm 0.09$ & $9.9 \pm 2.7$ & $0.92 \pm 0.05$ \\
\hline & $\mathrm{n}$ & 6 & 8 & 6 & 6 \\
\hline \multirow{2}{*}{ Group II } & Mean \pm SD & $19.4 \pm 1.7$ & $0.67 \pm 0.17$ & $12.9 \pm 1.8$ & $1.4 \pm 0.52$ \\
\hline & $\mathrm{n}$ & 6 & 6 & 6 & 6 \\
\hline \multirow{2}{*}{ Group III } & Mean \pm SD & $21.0 \pm 4.6^{\mathrm{b}}$ & $0.8 \pm 0.18^{\mathrm{a}}$ & $14.6 \pm 2.55^{* *_{a}}$ & $1.7 \pm 0.08^{* *}$ \\
\hline & $\mathrm{n}$ & 6 & 6 & 6 & 6 \\
\hline \multirow{2}{*}{ Group IV } & Mean \pm SD & $14.4 \pm 4.6^{* *}$ & $0.47 \pm 0.18^{*}$ & $7.3 \pm 1.8$ & $1.08 \pm 0.38$ \\
\hline & $\mathrm{n}$ & 7 & 7 & 7 & 7 \\
\hline
\end{tabular}

In Table 1, there are highly significant decreases in platelets count and hemoglobin concentration in tumorized mice (group IV) compared to the control mice (group I). On the other hand, the total volume of tumor cells reached $16 \mathrm{ml}$ in group IV, while, no tumor cells are found in groups I, II and III (Figures 1(a)-(d)).

The activities of (ALT) and (AST) in serum of mice of group IV are highly significantly and significantly increased respectively compared to those of group I, while, serum albumin of mice of group IV is highly significantly decreased compared to groups I, II and III (Table 2), (it is more clear in protein electrophoresis analysis in Figure 2). However, there is no significant difference between the tumorized treated group III and the normal groups I and II. In Figure 2 there are no difference between the electrophoresis pattern of the control (lane 1), tumorized mice-extract treated (lane 3), while a clear difference was found between tumorized mice-saline treated (lane 4) and the control (lane 1).

Table 3 shows that, the level of glucose and SOD activity in serum and erythrocytes GSH of mice of group IV are highly significantly and significantly decreased respectively compared to group I, while, MDA is highly significantly increased in GIV compared to GI. However, no significant difference was found between group III and groups I and II.

Table 4 shows a highly significant increase in serum levels of cholesterol, triglycerides and LDL of tumorized mice (group IV) compared to those of control (group I). On the other hand there is a highly significant decrease in total lipids in livers and serum HDL of mice of group IV compared to those of group I. However, no significant differences were observed in the levels of cholesterol, triglycerides, LDL and HDL in serum and total lipids in liver within groups I, II and the tumorized treated group III.

In Table 5, the liver and spleen weights are highly significantly decreased, while, DNA and RNA content in liver tissues are highly significantly increased in group IV compared to those of group I. However, no significant differences are observed in weights of liver and spleen in group III compared to group I (Figure 3(a), Figure 3(b)).

The correlations between the different parameters in all groups, liver DNA, RNA and MDA with GSH, SOD, glucose, Hb, HDL, AST, ALT and LDL are observed in Table 6. 

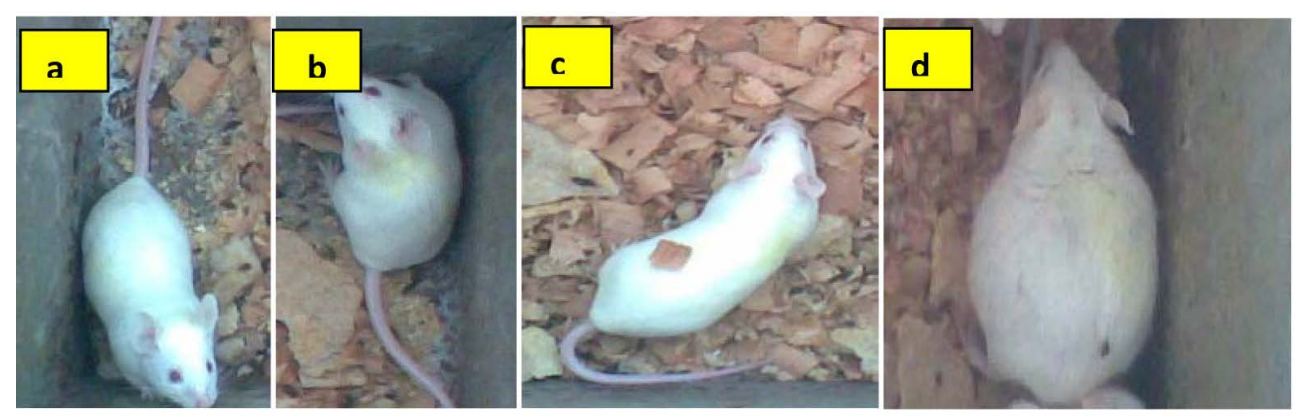

Figure 1. (a) Normal mice-saline treated (GI); (b) Normal mice Raphnus sativa extract treated (GII); (c) Ehrlich ascites carcinoma-bearing mice treated with Raphnus sativa extract (GIII) compared to (d) Ehrlich ascites carcinoma-bearing mice-saline treated (GIV).

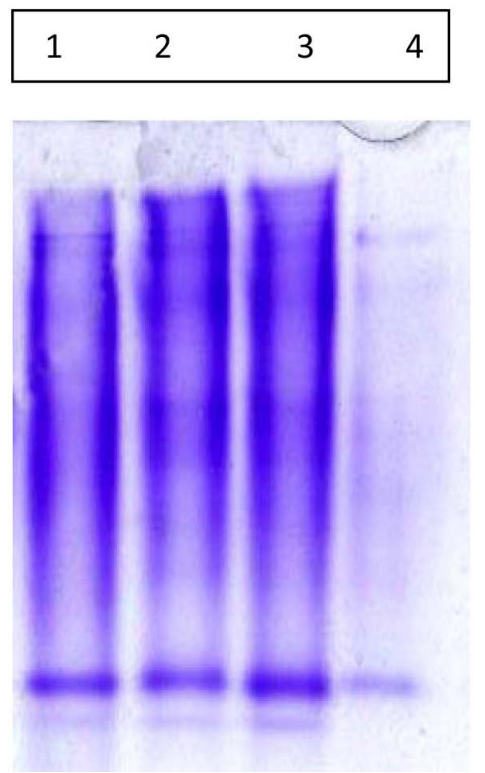

Figure 2. Separation of proteins in liver homogenate samples by polyacrylamide gel electrophoresis (PAGE) technique at $200 \mathrm{~V}$ for $1.5 \mathrm{~h}$. lane 1 represents normal mice-saline treated group as control (GI), lane 2 represents normal mice-Raphnus sativa extract treated group (GII), lane 3 represents tumorized mice-Raphnus sativa extract treated group (GIII), lane 4 represents tumorized mice-saline treated group (GIV).

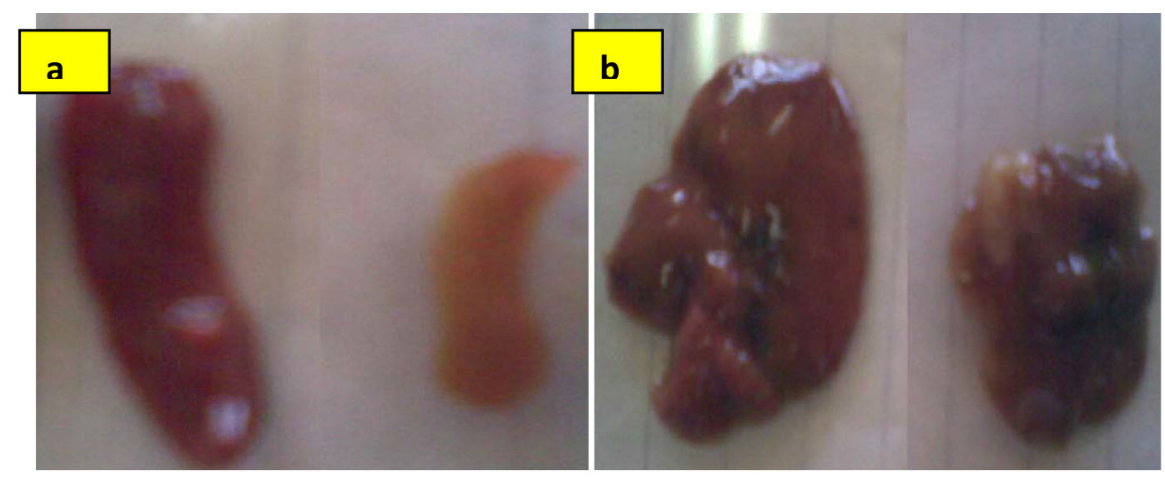

Figure 3. (a) Spleen of tumorized mice-Raphnus sativa extract treated (GIII) compared to spleen of tumorized mice-saline treated group (GIV); (b) Liver of tumorized mice-Raphnus sativa extract treated group (GIII) compared to liver of tumorized mice-saline treated group (GVI). 
Table 7 and Table 8 show that the levels of trace elements (Fe, $\mathrm{Zn}$ and $\mathrm{Cu}$ ) in spleen and liver tissues are significantly decreased in group IV compared to group I. However, the levels of these elements increased in group III than group IV.

\section{Discussion}

Superoxide anions are produced at any location where an electron transport chain is present, and hence $\mathrm{O}_{2}$ activation may occur in different compartments of the cells [30]. Therefore, it is not surprisingto find SODs in all these subcellular locations including the plant leaves which are used to scavenge these free radical species [35].

Oxidative stress is a disturbance in the balance between the formation of oxidizing species (reactive oxygen species and other radicals) and their effective removal by protective antioxidants. Overwhelming radicals generated in the blood stream and tissues can induce oxidative damage to cell membranes, which contain lipoproteins, proteins and deoxyribonucleic acid [32]. The present study suggests that, Raphnus sativus partial purified protein with SOD-like activity may be one of the treatment strategies. Ben Salah-Abbès, reported that, the extract of radishcontains many antioxidant compounds that protect against the toxicity resulting from mycotoxin (Zearalenone) [36] [37].

The elevations in serum activities of ALT and AST, and serum cholesterol, as well as decreases in serum albumin and total platelets count are expected in liver disease and in hepatocellular damage caused by a number of toxic agents [38] [39]. These disturbances in liver function may be as a result of the metastasis of tumor cells to the liver and the change in redox status [40]. Keisuke, reported that, a redox imbalance' subsequently induces liver tumor-promoting effects by enhancing cellular proliferation in rats [9]. Cancer cells exhibit increased glycolysis in combination with a reduced rate of respiration [41] [42]. In this study, serum glucose level of the tumorized-saline treated mice was significantly decreased than that of the tumorized extract-treated mice. The decrease in the glucose level was accompanied by reduction in the activity of SOD with a simultaneous increase in the oxidative stress marker (MDA). The level of MDA reflects the extent of membrane lipid peroxidation and hence cell membrane damage.

In the present study, serum cholesterol, triglycerides and LDL-c showed elevation in tumor-bearing mice saline-treated compared to those treated with the extract. The increase in serum levels of these lipid markers in the saline-treated tumor-bearing mice may be due to the fact that the tumor cells are energy consuming cells. Thus, these cells enhance the process of lipolysis from adipose tissues as well as other organs, including liver and spleen, with a resultant increase in the majority of serum lipid profile, while, the total lipid in liver tissue is highly significant decrease in addition to the dramatically decrease in liver and spleen weights. Based on the previous data, it can therefore expect to find positive correlations between both liver DNA and RNA with serum lipid profile. Such findings might be due to the metabolic disturbances accompanying death of EAC cell line and/or the modulation of the cytokines levels before and after treatment [43].

In addition, the present study revealed a significant decrease in the levels of GSH in blood of tumor-bearing mice saline-treated. Reduced glutathione is central to the cellular antioxidant defenses and acts as an important cofactor for antioxidant enzymes [44]. Under oxidative stress, glutathione is consumed by the glutathionerelated enzymes to detoxify peroxides produced because of increased lipid peroxidation [45] [46] and elevation in lipid peroxidation is a consequence of the depletion in GSH stores, which are otherwise capable of moderating the amount of lipid peroxidation.

Low levels of MDA indicate inhibition of lipidperoxidation. Thus the extract potentiates the activity of liverto fight against lipid peroxidation. This is well supported from total lipids results in liver. It is clear from this study that Raphnus sativus inhibits lipidperoxidation and provides protection by strengthening the antioxidantseffectby glutathione and catalase [47]. Taniguchi, reported that, the levels of lipid profile as well as the total lipids of the liver were disturbed during carcinogenesis and their levels were approximately return to the normal values after treatment with the extract [48].

Manganese superoxide dismutase (MnSOD) in the mitochondria plays an important role in cellular defense against oxidative damage [49]. The produced $\mathrm{OH}$ radical in the tumor cell may react with tyrosine, tryptophan and the thiol groups of the functional proteins and enzymes resulting in their inactivation [50] [51]. The highly reactive $\mathrm{OH}$ radicals can also attack DNA and can cause lipid peroxidation. After treatment with the SOD-like activity extract, the total enzyme activity (SOD) was elevated and the mean survival time of the tumor cells was reduced with a resultant decrease in the tumor volume. Most experimental models and cell culture studies have 
concluded that SOD has antiproliferative and tumor suppressor effects [52]. This may be one of the mechanisms by which Raphnus sativus extract kill the EAC cell line.

Furthermore, El-Sayedreported that, SOD activity was enhanced after treatment of the tumor cells with metal complexes having SOD-like activity, such type of treatment expresses excessive amount of $\mathrm{H}_{2} \mathrm{O}_{2}$ which implicated in EAC cell killing but not the normal cell because the latter cell contains sufficient catalase and/or peroxidase activities to degrade $\mathrm{H}_{2} \mathrm{O}_{2}$ [16].

Also, the use of substances with SOD-like activities can cause a pronounced activation of blood phagocytes. Moreover, Habib et al., extracted a similarmetalloprotein with MnSOD-like activity from the roots of Raphnus sativus and showed that, such extract can activate the immune system to kill the EAC cell line [53].

As apparent from the present results, liver DNA and RNA contents were significantly decreased after treatment of tumor-bearing mice with the extract. In contrast, liver lipid and protein contents in tumor-bearing mice extract-treated were increased compared with those of tumor-bearing mice saline-treated. These results are confirmed by the negative correlation between DNA and both total lipids and albumin where tumor growth is usually followed by total cell consumption of all energy sources including lipids and proteins. These results are in agreement with the findings of other author [54] who attributed their similar changes to tumor formation.

$\mathrm{Zn}, \mathrm{Cu}$ and $\mathrm{Mn}$ are cofactors of enzymes with important catalytic functions in the antioxidant defense system as superoxide dismutases. Mn-SOD is the major defense mechanism against mitochondrial reactive oxygen species that induce oxidative stress. $\mathrm{Cu} / \mathrm{Zn}-\mathrm{SOD}$ is known as a scavenger of superoxides. Therefore, the increase in heavy metals affect on the biological activity of the mice as well as nucleic acids and ribosomal activity of the cells of such mice [55].

Valko et al., showed that, a wide range of metabolic enzymes involved in energy transfer and antioxidants, require metal(s) ions as cofactors involved structurally in the enzyme proteins e.g. MnSOD, Cu-ZnSOD and FeSOD [1]. In the present study, the levels of $\mathrm{Cu}, \mathrm{Fe}, \mathrm{Mn}$ and $\mathrm{Zn}$ in liver and spleen tissues of the tumorizedextract treated mice were increased in compared with those of the tumorized-saline treated animal. These findings may be due to the use of these metals by the tumor cells during their proliferation and/or the need of these metals for incorporation in SOD isoenzymes in the treated animal group, a conclusion which was supported by the increase in the mean activity of SOD in the tumorized-extract treated mice. Also, it cannot neglect the fact that the extract contains $\mathrm{Cu}$ and $\mathrm{Mn}$ as well as higher levels of both Fe and $\mathrm{Zn}$.

\section{Conclusion}

In summary, the Raphnus sativus extract inhibited EAC cell growth possibly by compensating the decrease in SOD activity which was observed in serum of the tumor bearing mice. The mechanism may involve protection of the tumor suppressor genes from the toxic effects of free radicals. Consequently, liver metastasis can be suppressed after treatment with the prepared extract and this is clearly apparent in the normal levels of all liver investigated parameters after treatment with the partial purified protein. Moreover, the role of Raphnus sativus extract in the enhancement of the immune system function cannot be neglected. Therefore, it is recommended to use the Raphnus sativus in many of our daily diets and in production of antioxidantsto protect against the toxic effects of the free radicals.

\section{References}

[1] Valko, M., et al. (2006) Free Radicals, Metals and Antioxidants in Oxidative Stress-Induced Cancer. Chemico-Biological Interactions, 160, 1-40. http://dx.doi.org/10.1016/j.cbi.2005.12.009

[2] Pham-Huy, L.A., He, H. and Pham-Huy, C. (2008) Free Radicals, Antioxidants in Disease and Health. International Journal of Biomedical Science, 4, 89-96.

[3] Ridnour, L.A., et al. (2005) Nitric Oxide Regulates Angiogenesis through a Functional Switch Involving Thrombospondin-1. Proceedings of the National Academy of Sciences of the United States of America, 102, 13147-13152. http://dx.doi.org/10.1073/pnas.0502979102

[4] Dröge, W. (2002) Free Radicals in the Physiological Control of Cell Function. Physiological Reviews, 82, 47-95. http://dx.doi.org/10.1152/physrev.00018.2001

[5] Halliwell, B. and Gutteridge, J.M. (2015) Free Radicals in Biology and Medicine. Oxford University Press, USA. http://dx.doi.org/10.1093/acprof:oso/9780198717478.001.0001

[6] Land, E. (2009) Free Radicals in Biology and Medicine. Taylor \& Francis. 
[7] Halliwell, B. and Gutteridge, J.M. (1986) Oxygen Free Radicals and Iron in Relation to Biology and Medicine: Some Problems and Concepts. Archives of Biochemistry and Biophysics, 246, 501-514. http://dx.doi.org/10.1016/0003-9861(86)90305-X

[8] Touati, D. (1997) Superoxide Dismutases in Bacteria and Pathogen Protists. Cold Spring Harbor Monograph Archive, 34, 447-493.

[9] Shimamoto, K., et al. (2011) Indole-3-Carbinol Enhances Oxidative Stress Responses Resulting in the Induction of Preneoplastic Liver Cell Lesions in Partially Hepatectomized Rats Initiated with Diethylnitrosamine. Toxicology, 283, 109-117. http://dx.doi.org/10.1016/j.tox.2011.03.003

[10] Pastore, A., et al. (2003) Analysis of Glutathione: Implication in Redox and Detoxification. Clinica Chimica Acta, 333, 19-39. http://dx.doi.org/10.1016/S0009-8981(03)00200-6

[11] Fidler, I.J. (2003) The Pathogenesis of Cancer Metastasis: The "Seed and Soil” Hypothesis Revisited. Nature Reviews Cancer, 3, 453-458. http://dx.doi.org/10.1038/nrc1098

[12] Gupta, G.P. and Massagué, J. (2006) Cancer Metastasis: Building a Framework. Cell, 127, 679-695. http://dx.doi.org/10.1016/j.cell.2006.11.001

[13] Brunner, L.S., et al. (2010) Brunner \& Suddarth’s Textbook of Medical-Surgical Nursing. Vol. 1, Lippincott Williams \& Wilkins.

[14] Chaturvedi, P. and Akala, H. (2001) Effect of Raphanus sativus Root Extracts on Glucose Level in Normal and Diabeticrats. Journal of Applied Zoological Researches, 12, 172-177.

[15] Sipos, P., et al. (2002) Effects of Black Radish Root (Raphanus sativus L. Var Niger) on the Colon Mucosa in Rats Fed a Fat Rich Diet. Phytotherapy Research, 16, 677-679. http://dx.doi.org/10.1002/ptr.950

[16] Hanlon, P.R., Webber, D.M. and Barnes, D.M. (2007) Aqueous Extract from Spanish Black Radish (Raphanus sativus L. Var. niger) Induces Detoxification Enzymes in the HepG2 Human Hepatoma Cell Line. Journal of Agricultural and Food Chemistry, 55, 6439-6446. http://dx.doi.org/10.1021/jf070530f

[17] Lugasi, A., et al. (2005) Antioxidant Effect of Squeezed Juice from Black Radish (Raphanus sativus L. Var niger) in Alimentary Hyperlipidaemia in Rats. Phytotherapy Research, 19, 587-591. http://dx.doi.org/10.1002/ptr.1655

[18] Salah-Abbès, J.B., et al. (2008) Tunisian Radish Extract Raphanus sativus Enhances the Antioxidant Status and Protects against Oxidative Stress Induced by Zearalenone in Balb/c Mice. Journal of Applied Toxicology, 28, 6-14. http://dx.doi.org/10.1002/jat.1240

[19] EL-Sayd, I. (1998) Effect of Some Complexes on Tumor-Bearing Animals. PhD Thesis, Mansoura University, Mansoura, 7.

[20] Lowry, O.H., Rosebrough, N.J., Farr, A.L. and Randall, R.J. (1951) Protein Measurement with the Folin Phenol Reagent. The Journal of Biological Chemistry, 193, 265-275.

[21] Rosner, F. and Gorfien, P.C. (1968) Erythrocyte and Plasma Zinc and Magnesium Levels in Health and Disease. Journal of Laboratory and Clinical Medicine, 72, 213-219.

[22] Schneider, W.C. (1946) Intracellular Distribution of Enzymes, Distribution of Succinic Dehydrogenase, Cytochrome Oxidase, Adenosinetriphosphatase, and Phosphorus Compounds in Normal Ratliver and in Rat Hepatomas. Cancer Research, 6, 685-690.

[23] Dische, Z. and Shettles, L.B. (1948) A Specific Color Reaction of Methylpentoses and a Spectrophotometric Micromethod for Their Determination. Journal of Biological Chemistry, 175, 595-603.

[24] Meijbaum, W. (1939) Estimation of small amounts of pentose especially in derivatives of adenylic acid. Zeitschrift fur physiologische Chemie, 258, 117-120.

[25] Littlefield, J.W., Keller, E.B., Gross, J. and Paul Zamecnik, C. (1955) Studies on Cytoplasmic Ribonucleoprotein Particles from the Liver of the Rat. Journal of Biological Chemistry, 217, 111-124.

[26] Knight, J.A. anderson, S. and Rawle, J.M. (1972) Chemical Basis of the Sulfo-Phospho-Vanillin Reaction for Estimating Total Serum Lipids. Clinical Chemistry, 18, 199-202.

[27] Schaffert, R.R., Kingsley, G.R. and Getchell, G. (1964) Automated Determination of Serum Glutamic Oxalacetic and Glutamic Pyruvic Transaminase. Clinical Chemistry, 10, 519-532.

[28] Doumas, B.T., Watson, W.A. and Biggs, H.G. (1971) Albumin Standards and the Measurement of Serum Albumin with Bromcresol Green. Clinica Chimica Acta, 31, 87-96. http://dx.doi.org/10.1016/0009-8981(71)90365-2

[29] Doumas, B.T., Watson, W.A. and Biggs, H.G. (1997) Albumin Standards and the Measurement of Serum Albumin with Bromcresol Green. Clinica Chimica Acta, 258, 21-30. http://dx.doi.org/10.1016/S0009-8981(96)06447-9

[30] Beutler, E., Duron, O. and Kelly, B.M. (1963) Improved Method for the Determination of Blood Glutathione. The Journal of Laboratory and Clinical Medicine, 61, 882-888. 
[31] Stocks, J. and Dormandy, T. (1971) The Autoxidation of Human Red Cell Lipids Induced by Hydrogen Peroxide. British Journal of Haematology, 20, 95-111. http://dx.doi.org/10.1111/j.1365-2141.1971.tb00790.x

[32] Salin, M.L. and McCord, J.M. (1974) Superoxide Dismutases in Polymorphonuclear Leukocytes. Journal of Clinical Investigation, 54, 1005-1009. http://dx.doi.org/10.1172/JCI107816

[33] Drabkin, D.L. and Austin, J.H. (1932) Spectrophotometric Studies: I. Spectrophotometric Constants for Common Hemoglobin Derivatives in Human, Dog, and Rabbit Blood. Journal of Biological Chemistry, 98, 719-733.

[34] Schubert, G. (1984) Niere Und Ableitende Harnwege. In: Bässler, R., et al., Eds., Pathologie, Springer, Berlin, 1-129. http://dx.doi.org/10.1007/978-3-642-69456-1 1

[35] Alscher, R.G., Erturk, N. and Heath, L.S. (2002) Role of Superoxide Dismutases (SODs) in Controlling Oxidative Stress in Plants. Journal of Experimental Botany, 53, 1331-1341. http://dx.doi.org/10.1093/jexbot/53.372.1331

[36] Crimi, E., et al. (2004) The Beneficial Effects of Antioxidant Supplementation in Enteral Feeding in Critically Ill Patients: A Prospective, Randomized, Double-Blind, Placebo-Controlled Trial. Anesthesia \& Analgesia, 99, 857-863. http://dx.doi.org/10.1213/01.ANE.0000133144.60584.F6

[37] Block, K.I., Koch, A.C., Mead, M.N., Tothy, P.K., Newman, R.A. and Gyllenhaal, C. (2007) Impact of Antioxidant Supplementation on Chemotherapeutic Efficacy: A Systematic Review of the Evidence from Randomized Controlled Trials. Cancer Treatment Reviews, 33, 407-418. http://dx.doi.org/10.1016/j.ctrv.2007.01.005

[38] Salah-Abbès, J.B., Abbès, S., Abdel-Wahhab, M.A. and Oueslati, R. (2009) Raphanus sativus Extract Protects against Zearalenone Induced Reproductive Toxicity, Oxidative Stress and Mutagenic Alterations in Male Balb/c Mice. Toxicon, 53, 525-533. http://dx.doi.org/10.1016/j.toxicon.2009.01.013

[39] Beevi, S.S., Narasu, M.L. and Gowda, B.B. (2010) Polyphenolics Profile, Antioxidant and Radical Scavenging Activity of Leaves and Stem of Raphanus sativus L. Plant Foods for Human Nutrition, 65, 8-17. http://dx.doi.org/10.1007/s11130-009-0148-6

[40] Greengard, O. (1979) Detection of Extrahepatic Cancer by Alterations in Hepatic Functions. Biochemical Pharmacology, 28, 2569-2572. http://dx.doi.org/10.1016/0006-2952(79)90028-5

[41] Ames, B.N. (1983) Dietary Carcinogens and Anticarcinogens Oxygen Radicals and Degenerative Diseases. Science, 221, 1256-1264. http://dx.doi.org/10.1126/science.6351251

[42] Waris, G. and Ahsan, H. (2006) Reactive Oxygen Species: Role in the Development of Cancer and Various Chronic Conditions. Journal of Carcinogenesis, 5, 14. http://dx.doi.org/10.1186/1477-3163-5-14

[43] Korekane, H., Nishikawa, A. and Imamura, K. (2003) Mechanisms Mediating Metabolic Abnormalities in the Livers of Ehrlich Ascites Tumor-Bearing Mice. Archives of Biochemistry and Biophysics, 412, 216-222. http://dx.doi.org/10.1016/S0003-9861(03)00041-9

[44] Hayes, J.D., Flanagan, J.U. and Jowsey, I.R. (2005) Glutathione Transferases. Annual Review of Pharmacology and Toxicology, 45, 51-88. http://dx.doi.org/10.1146/annurev.pharmtox.45.120403.095857

[45] Cathcart, R.F. (1985) Vitamin C: The Nontoxic, Nonrate-Limited, Antioxidant Free Radical Scavenger. Medical hypotheses, 18, 61-77. http://dx.doi.org/10.1016/0306-9877(85)90121-5

[46] El-Gendy, K.S., Alyb, N.M., Mahmoudb, F.H., Kenawyb, A. and El-Sebaea, A.K.H. (2010) The Role of Vitamin C as Antioxidant in Protection of Oxidative Stress Induced by Imidacloprid. Food and chemical Toxicology, 48, 215-221. http://dx.doi.org/10.1016/j.fct.2009.10.003

[47] Chaturvedi, P. (2008) Inhibitory Response of Raphanus sativus on Lipid Peroxidation in Albino Rats. Evidence-Based Complementary and Alternative Medicine, 5, 55-59. http://dx.doi.org/10.1093/ecam/nel077

[48] Taniguchi, M., Sasaki, N., Tsuge, T., Aoyama, T. and Oka, A. (2007) ARR1 Directly Activates Cytokinin Response Genes That Encode Proteins with Diverse Regulatory Functions. Plant and Cell Physiology, 48, 263-277. http://dx.doi.org/10.1093/pcp/pcl063

[49] Zhang, Y., et al. (2010) Loss of Manganese Superoxide Dismutase Leads to Abnormal Growth and Signal Transduction in Mouse Embryonic Fibroblasts. Free Radical Biology and Medicine, 49, 1255-1262. http://dx.doi.org/10.1016/j.freeradbiomed.2010.07.006

[50] Sinha, B.K. (1989) Free Radicals Inanticancer Drug Pharmacology. Chemico-Biological Interactions, 69, $293-317$. http://dx.doi.org/10.1016/0009-2797(89)90117-8

[51] Zhou, Y., Hileman, E.O., Plunkett, W., Keating, M.J. and Huang, P. (2003) Free Radical Stress in Chronic Lymphocytic Leukemia Cells and Its Role in Cellular Sensitivity to ROS-Generating Anticancer Agents. Blood, 101, 40984104. http://dx.doi.org/10.1182/blood-2002-08-2512

[52] Oberley, T. and Oberley, L. (1997) Antioxidant Enzyme Levels in Cancer. Histology and Histopathology, 12, 525-535.

[53] Eissa, L.A., Habib, S.A. and Latif, M.M.A. (2014) Inhibitory Effect of the Partially Purified Protein from Raphanus 
sativus Roots and Low-Molecular-Weight Heparin on Ehrlich Ascites Carcinoma Bearing Mice. Egyptian Journal of Basic and Applied Sciences, 1, 88-96. http://dx.doi.org/10.1016/j.ejbas.2014.05.002

[54] Esmat, A. (1990) Studies of the Effect of a Naturally Occurring Compound on Some Biochemical Markers for Cancer in Mice. PhD Thesis, Biochemistry Department, Faculty of Science.

[55] Mathers, E., Houlihan, D.F., McCarthy, I.D. and Burren, L.J. (1993) Rates of Growth and Protein Synthesis Correlated with Nucleic Acid Content in Fry of Rainbow Trout, Oncorhynchus mykiss: Effects of Age and Temperature. Journal of Fish Biology, 43, 245-263. http://dx.doi.org/10.1111/j.1095-8649.1993.tb00426.x

\section{Submit or recommend next manuscript to SCIRP and we will provide best service for you:}

Accepting pre-submission inquiries through Email, Facebook, Linkedin, Twitter, etc A wide selection of journals (inclusive of 9 subjects, more than 200 journals)

Providing a 24-hour high-quality service

User-friendly online submission system

Fair and swift peer-review system

Efficient typesetting and proofreading procedure

Display of the result of downloads and visits, as well as the number of cited articles

Maximum dissemination of your research work

Submit your manuscript at: http://papersubmission.scirp.org/ 